\title{
Dexamethasone implant in retinal vein occlusions
}

\author{
Sang Beom Han \\ Moosang Kim \\ Seung-Jun Lee \\ Department of Ophthalmology, \\ School of Medicine, Kangwon \\ National University, Chuncheon, \\ South Korea
}

This article was published in the following Dove Press journal:

Clinical Ophthalmology

22 August 2016

Number of times this article has been viewed

\section{Dear editor}

We read the article entitled "Therapeutic effect of dexamethasone implant in retinal vein occlusions resistant to anti-VEGF therapy" by Wallsh et al with great interest. ${ }^{1}$ The authors investigated the efficacy of the intravitreal dexamethasone (DEX) implant in patients with retinal vein occlusions (RVOs) who have failed multiple anti-vascular endothelial growth factor (anti-VEGF) injections. They concluded that DEX should be considered as a treatment option in patients with RVOs who have failed anti-VEGF therapy. We congratulate the authors for this well-organized study, and would like to contribute to their findings.

Compared with anti-VEGF therapies, DEX implant can reduce the number of injections in patients with RVOs. In patients with macular edema-associated RVOs not responsive to repetitive anti-VEGF therapies, the treatment effect after DEX implant treatment is encouraging. However, these results are achieved at the expense of adverse effects typically associated with steroids: Recent study demonstrated that intravitreal injection of DEX implant was associated with ocular hypertension in $32.6 \%$ of the eyes. ${ }^{2}$ Previous glaucoma and ocular hypertension are risk factors for this increase. Thus, careful monitoring of intraocular pressure is very important to receive DEX implant in patients with RVOs. In addition, phakic patients have to expect cataract progression, with the need for cataract surgery within several years.

\section{Acknowledgment}

This study was supported by 2012 Research Grant from Kangwon National University.

\section{Disclosure}

The authors report no conflicts of interest in this communication.

\section{References}

1. Wallsh J, Sharareh B, Gallemore R. Therapeutic effect of dexamethasone implant in retinal vein occlusions resistant to anti-VEGF therapy. Clin Ophthalmol. 2016;10:947-954.

2. Mazzarella S, Mateo C, Freixes S, et al. Effect of intravitreal injection of dexamethasone $0.7 \mathrm{mg}\left(\mathrm{Ozurdex}^{\circledR}\right)$ on intraocular pressure in patients with macular edema. Ophthalmic Res. 2015;54(3):143-149. 


\section{Authors' reply}

Josh Wallsh

Ron Gallemore

Retina Macula Institute, Torrance, CA, USA

Correspondence: Ron Gallemore

Retina Macula Institute, 420I Torrance Blvd Ste 220, Torrance,

CA 90503, USA

Tel +I 3109449393

Fax + I 3109443393

Email rongallemoremd@gmail.com

\section{Dear editor}

We would like to thank Dr Han and associates for their interest in our article. ${ }^{1}$ We were interested to read "Dexamethasone implant in retinal vein occlusions" by Han et al.

We agree that the adverse effects associated with intravitreal dexamethasone implant need to be considered prior to treatment. In our study, the level of cataract progression was higher than previously reported, which was important since dexamethasone implants are perceived to be less toxic to the lens than other steroids. Haller et al previously reported an ocular hypertension rate of $32.8 \%$ similar to that observed by Mazzarella et al., ${ }^{2,3}$ The development of ocular hypertension in our study cohort was well below these previously reported levels, but this is still an important adverse reaction to be monitoring for. By initiating treatment with intravitreal dexamethasone implants patients must be aware of the risk of possible surgical or medical management of cataracts and glaucoma. This must be weighed against the numerous benefits associated with such treatment.

\section{Disclosure}

The authors report no conflicts of interest in this communication.

\section{References}

1. Wallsh J, Sharareh B, Gallemore R. Therapeutic effect of dexamethasone implant in retinal vein occlusions resistant to anti-VEGF therapy. Clin Ophthalmol. 2016;10:947-954.

2. Haller JA, Bandello F, Belfort R Jr, et al. Dexamethasone intravitreal implant in patients with macular edema related to branch or central retinal vein occlusion: twelve-month study results. Ophthalmology. 2011; 118(12):2453-2460.

3. Mazzarella S, Mateo C, Freixes S, et al. Effect of intravitreal injection of dexamethasone $0.7 \mathrm{mg}\left(\mathrm{Ozurdex}{ }^{\circledR}\right)$ on intraocular pressure in patients with macular edema. Ophthalmic Res. 2015;54(3):143-149.

Dove Medical Press encourages responsible, free and frank academic debate. The content of the Clinical Ophthalmology 'letters to the editor' section does not necessarily represent the views of Dove Medical Press, its officers, agents, employees, related entities or the Clinical Ophthalmology editors. While all reasonable steps have been taken to confirm the content of each letter, Dove Medical Press accepts no liability in respect of the content of any letter, nor is it responsible for the content and accuracy of any letter to the editor.

Clinical Ophthalmology

\section{Publish your work in this journal}

Clinical Ophthalmology is an international, peer-reviewed journal covering all subspecialties within ophthalmology. Key topics include: Optometry; Visual science; Pharmacology and drug therapy in eye diseases; Basic Sciences; Primary and Secondary eye care; Patient Safety and Quality of Care Improvements. This journal is indexed on

\section{Dovepress}

PubMed Central and CAS, and is the official journal of The Society of Clinical Ophthalmology (SCO). The manuscript management system is completely online and includes a very quick and fair peer-review system, which is all easy to use. Visit http://www.dovepress.com/ testimonials.php to read real quotes from published authors. 